\title{
$28 \mathrm{~W} / \mathrm{cm}^{3}$ high power density three-port DC/DC converter cell for dual-voltage $12-\mathrm{V} / 48-\mathrm{V}$ HEV subsystem
}

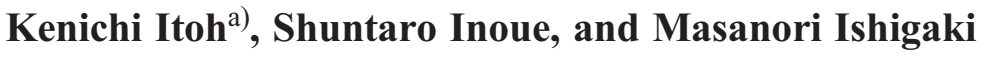 \\ System \& Electronics Engineering Dept. II, TOYOTA CENTRAL R\&D LABS., INC., \\ 41-1 Yokomichi, Nagakute, Aichi 480-1192, Japan \\ a)ken-ito@mosk.tytlabs.co.jp
}

\begin{abstract}
Realizing both of compact and low energy consumption is technical issue on development of electricity-rich automotive subsystems. In the present work, a $12-\mathrm{V} / 48-\mathrm{V}$ dual-voltage subsystem using three-port DC/DC converter cells is proposed, and the high power density cell design is studied to achieve ultra-compact subsystem in hybrid-electric-vehicle. A $500 \mathrm{~W}, 400 \mathrm{kHz}$ prototype is developed with GaN FETs, and its efficiencies are evaluated. The prototype achieves power density of $28 \mathrm{~W} / \mathrm{cm}^{3}$ at rated power, and its efficiency is measured more than $91 \%$ over a wide output power range, with a maximum efficiency of $93.7 \%$.
\end{abstract}

Keywords: multiport circuit, DC-DC power conversion, GaN FET, bridge circuit, multi-cell

Classification: Power devices and circuits

\section{References}

[1] J. G. Kassakian, et al.: "Automotive electrical systems-the power electronics market of the future," IEEE Applied Power Electronics Conference and Exposition, 2000, APEC 2000 (2000) (DOI: 10.1109/APEC.2000.826075).

[2] T. Teratani: "Impact of DC48V on automotive power supply systemsComparison with DC42V and future view under DC60V," IEEJ Trans. Ind. Appl. 135 (2015) 892 (DOI: 10.1541/ieejias.135.892).

[3] M. Kasper, et al.: "Hardware verification of a hyper-efficient (98\%) and supercompact $(2.2 \mathrm{~kW} / \mathrm{dm} 3)$ isolated $\mathrm{AC} / \mathrm{DC}$ telecom power supply module based on multi-cell converter approach," Applied Power Electronics Conference and Exposition (APEC) (2015) (DOI: 10.1109/APEC.2015.7104333).

[4] H. Tao, et al.: "Family of multiport bidirectional DC-DC converters," IEE Proc., Electr. Power Appl. 153 (2006) 451 (DOI: 10.1049/ip-epa:20050362).

[5] Z. Qian, et al.: "Modeling and control of three-port DC/DC converter interface for satellite applications," IEEE Trans. Power Electron. 25 (2010) 637 (DOI: 10.1109/TPEL.2009.2033926).

[6] M. Ishigaki, et al.: "A new isolated multi-port converter using interleaving and magnetic coupling inductor technologies," Applied Power Electronics Conference and Exposition (APEC) (2013) (DOI: 10.1109/APEC.2013.6520432). 
[8] A. Saito, et al.: "Efficiency analysis of SiC-MOSFET-based bidirectional isolated DC/DC converters," IEICE Trans. Electron. E99-C (2016) 1065 (DOI: 10.1587/transele.E99.C.1065).

[9] P.-L. Wong, et al:: "Performance improvements of interleaving VRMs with coupling inductors," IEEE Trans. Power Electron. 16 (2001) 499 (DOI: 10. $1109 / 63.931059)$.

[10] K. Itoh, et al.: "Loss estimation of an isolated three-port DC-DC converter for automotive applications," IEEE Energy Conversion Congress and Exposition (ECCE) (2015) (DOI: 10.1109/ECCE.2015.7310178).

\section{Introduction}

Driven by the high demands of low emission automotive, the technologies that can improve the fuel efficiency have been actively researched. For the automotive subsystem, DC 12-V bus with lead acid battery is conventionally used. However, the 12-V current load is rapidly increased with development of automotives [1]. Heavier load current causes high energy consumption in wire-harness and conversion circuits. Dual-voltage subsystem including DC 48-V bus has been developed to mitigate the current load from the classic 12-V bus [2], and it will be also a promising technology to reduce the energy consumption in hybrid-electric-vehicle (HEV). Additionally, an approach of multi-cell converter has been published to realize high efficient and compact size in a power conversion circuit [3]. Fig. 1(a) shows an example of multi-cell structure for a dual-voltage $12-\mathrm{V} / 48-\mathrm{V} \mathrm{HEV}$ subsystem using conventional converters. By connecting several of converter cells in series at the high voltage port, the voltage stress is shared by the cells, and low

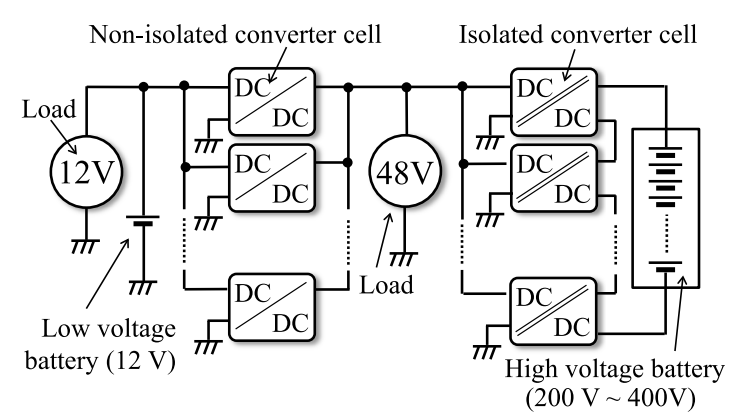

(a) System using conventional isolated and non-isolated converter cells

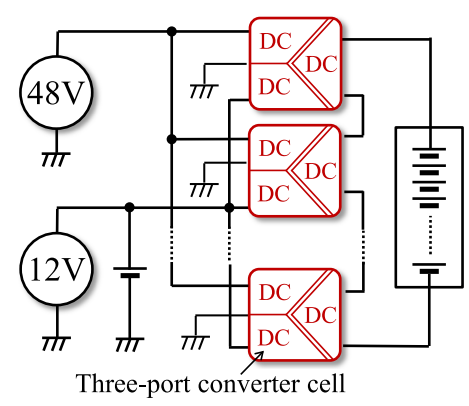

(b) Proposed multi-cell structure using three-port converter cells

Fig. 1. Multi-cell structure for $12-\mathrm{V} / 48-\mathrm{V}$ HEV subsystem 
voltage semiconductor devices which have lower on-resistance can be employed. Moreover, parallel interleaving of low voltage (high current) ports can decrease the current to reduce the conduction loss of each cell. The multi-cell approach has an attempt to significantly reduce the converter losses, however, dual-voltage subsystem requires many converter cells for each DC bus. On the one hand, multi-port DC/DC converter topologies were studied in order to reduce circuit components $[4,5]$, and a three-port converter which integrates an isolated converter (Dual active bridge; DAB) and a non-isolated converter (Multi-phase converter) has been proposed in [6]. Fig. 1(b) shows the proposed 12-V/48-V multi-cell structure using three-port converter cells. The proposed subsystem has an advantage of reducing the number of cell. In the present work, a high power density three-port converter cell is developed for realizing compact and low energy consumption in HEV subsystem. To achieve high power density, 500-W, $400-\mathrm{kHz}$ prototype is constructed with GaN FETs, and its efficiencies are measured in rated power.

\section{Circuit topology and operation principle}

The schematic of three-port DC/DC converter using a coupling inductor technique [6] is described in Fig. 2. The converter has a transformer and a positive coupled inductor, and their windings are connected to the middle points of full-bridges $M_{\mathrm{u}}$, $M_{\mathrm{v}}, M_{\alpha}$, and $M_{\beta}$, respectively. The primary winding of transformer has a center-tap which connects an extra DC port (port C). There are three DC ports referred as port $\mathrm{A}$, port $\mathrm{B}$, and port $\mathrm{C}$ in one circuit, and the $\mathrm{DC}$ power can be transferred mutually. As shown in Fig. 3, two different circuit topologies are integrated in the converter. $\mathrm{DAB}$ converter $[7,8]$ operates between port $\mathrm{A}$ and port $\mathrm{B}$, and its isolated DC power is controlled by adjusting phase angle difference $\phi$ of two full-bridges. Then, the transformer is excited and the coupling inductor shows low inductances against differential mode current. On the one hand, the multi-phase converter [9] operates between port $\mathrm{A}$ and port $\mathrm{C}$. The voltage ratio of $V_{\mathrm{A}} / V_{\mathrm{C}}$ can be controlled by adjusting the duty ratio $\delta$. The coupling inductor shows high inductance against common mode current, and the flux of transformer can be cancelled out. Hence, two topologies are integrated without additional magnetic components since they have different inductance for each current mode.

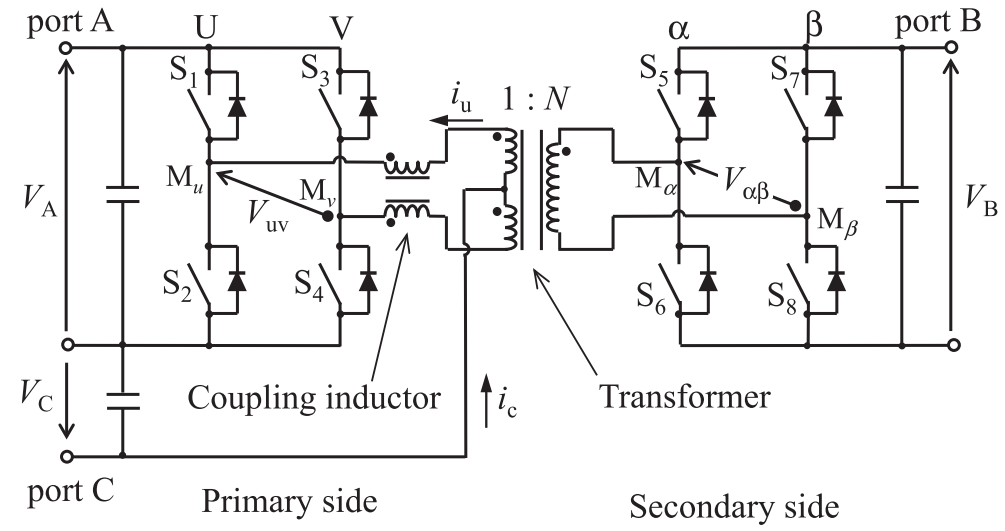

Fig. 2. Schematic of the three-port DC/DC converter 


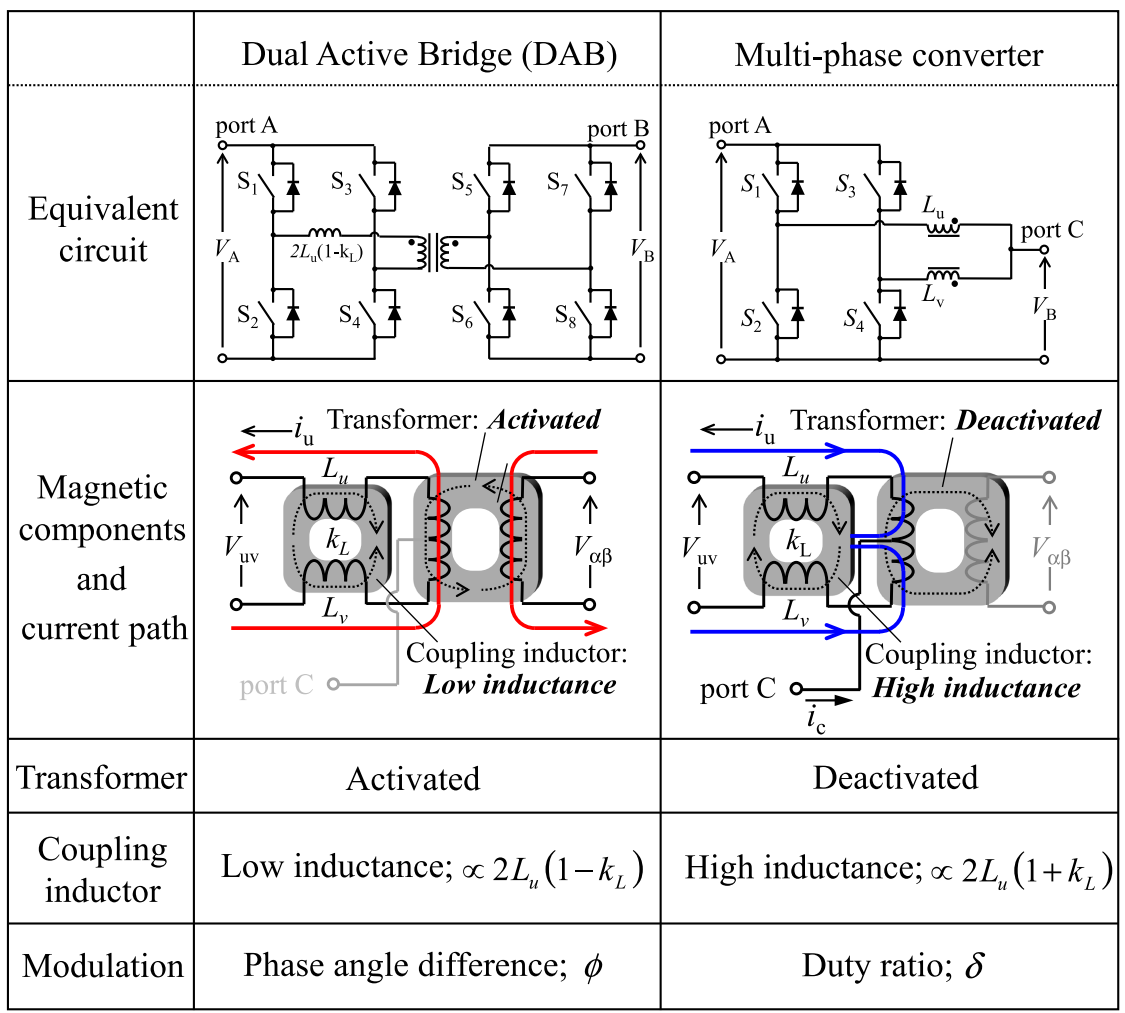

Fig. 3. Equivalent circuit of two topologies, and impedance behavior of magnetic components for each circuit topology.

\section{Prototype design}

Fig. 4 shows the thermal heat path for the board-mounted transistor and thermal resistances. The sum of thermal resistances is calculated as $R_{\text {th }}=22.7 \mathrm{~K} / \mathrm{W}$ (Table I). The allowable FET power dissipation $P_{\mathrm{FET}}$ can be calculated as $P_{\mathrm{FET}}=\left(T_{\text {jmax }}-T_{\mathrm{amb}}\right) / R_{\mathrm{th}}=5.3 \mathrm{~W}$, where $T_{\text {jmax }}$ is the maximum junction temperature of $150^{\circ} \mathrm{C}$ and $T_{\mathrm{amb}}$ is the ambient temperature of $30^{\circ} \mathrm{C}$. As for the three-port converter, the low-voltage primary side FET dissipates large losses because high current goes through the primary windings. Thus, the power dissipation of primary FETs is the matter to be considered in determining the switching frequency.

In order to design the prototype and its switching frequency, turn-off switching losses of a $100 \mathrm{~V}$-Si MOSFET (BSC046N10NS3, $R_{\text {on }}=4.6 \mathrm{~m} \Omega$ ) and an $80-\mathrm{V} \mathrm{GaN}$ FET (EPC2021, $R_{\text {on }}=2.5 \mathrm{~m} \Omega$ ) are measured with a double-pulsed test circuit [10]. As shown in Fig. 5(a), turn-off losses can be decreased by employing GaN FETs for a primary full-bridge. Fig. 5(b) shows calculated power dissipations in single FET as function of switching frequency. The dissipation at switching frequency of $f_{\mathrm{sw}}=0 \mathrm{~Hz}$ is equal to $\mathrm{FET}$ conduction losses. The power dissipation of $\mathrm{Si}$ MOSFET is rapidly increased because of its large switching losses, and the power dissipation exceeds the allowable value of $P_{\mathrm{FET}}=5.3 \mathrm{~W}$ at $f_{\mathrm{sw}}=180 \mathrm{kHz}$. On the other hand, the single GaN FET can be operated at $f_{\mathrm{sw}} \geq 400 \mathrm{kHz}$. Therefore, a prototype has been constructed with GaN FETs, and its magnetic components were designed at the switching frequency of $400 \mathrm{kHz}$. Fig. 6 shows the prototype of $500 \mathrm{~W}, 400 \mathrm{kHz}$ three-port converter cell. The power stage and the gate drive circuit (without controller IC) are enclosed by an aluminium housing, and total volume of 
Table I. Thermal resistances

\begin{tabular}{c|c|c}
\hline Layer & Symbol & Thermal resistance $[\mathrm{K} / \mathrm{W}]$ \\
\hline FET topside & $R_{\mathrm{jc}}$ & 0.4 \\
\hline Thermal gel & $R_{\mathrm{gel}}$ & 6.4 \\
\hline Aluminium housing & $R_{\mathrm{hou}}$ & 0.2 \\
\hline Thermal grease & $R_{\mathrm{gre}}$ & 0.8 \\
\hline Passive heat sink & $R_{\mathrm{h} / \mathrm{s}}$ & 15.0 \\
\hline
\end{tabular}

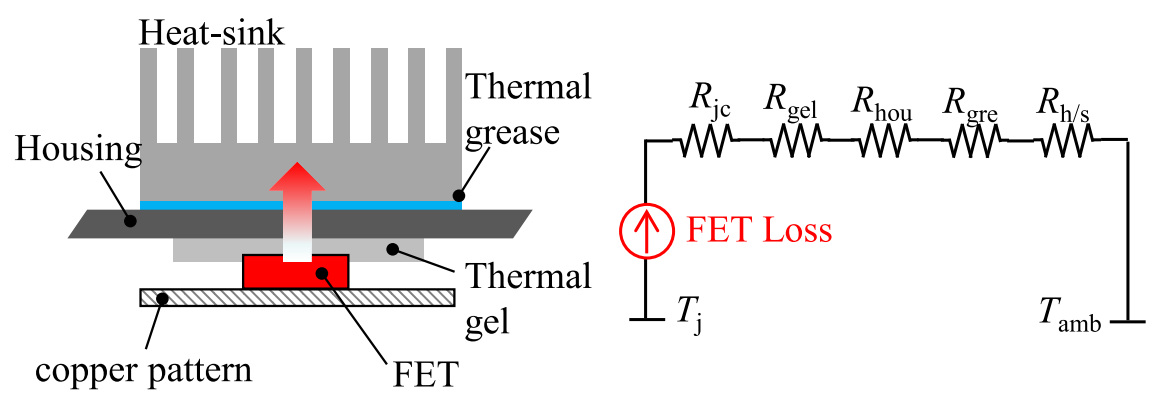

Fig. 4. Thermal diagram and its resistances of board-mounted transistor.

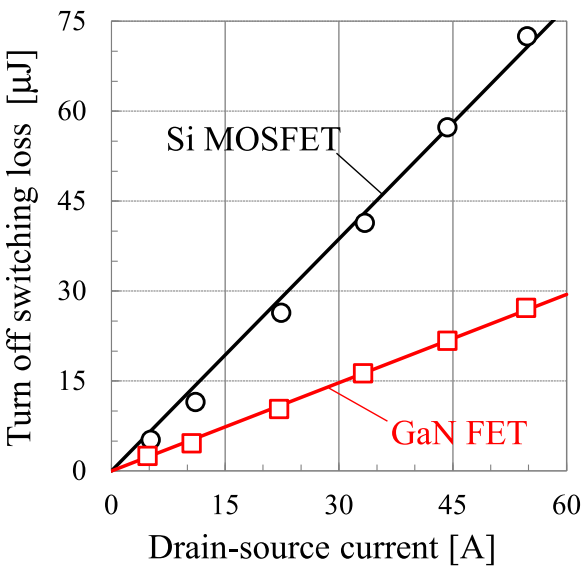

(a)

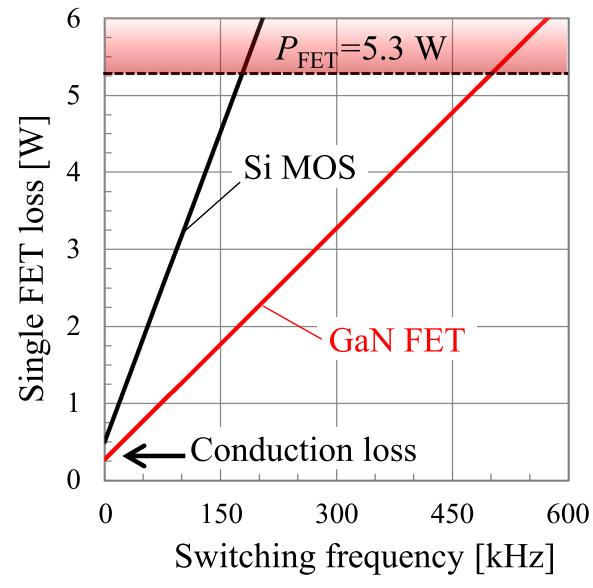

(b)

Fig. 5. (a) Measured turn-off switching losses, and (b) Power dissipation of single FET.

$18 \mathrm{~cm}^{3}(6.0 \times 4.0 \times 0.75 \mathrm{~cm})$ is achieved. The GaN FET half-bridge sub-board (EPC, EPC9203) which contains 80-V, 90-A GaN FETs (EPC, EPC2021) is commercially available, and it is used for primary full-bridge. For the secondary side full-bridge, a half-bridge sub-board was designed using 200-V, 25-A GaN FETs (EPC, EPC2010c). As shown in Fig. 6, sub-board has ceramic capacitors and driver ICs (TI, LM5104), and they are mounted on four-layer PCB with a $70 \mu \mathrm{m}$ copper pattern. The sub-board has a metal pad at bottom side, and it is connected to power stage which has four-layer main-board with a $175 \mu \mathrm{m}$ copper pattern.

A ferrite planar core (TDK, PC95EL18X7.3-Z) was employed for transformer and coupling inductor. The transformer core has no air gap and turn ratio is $N=2$, 
and the number of primary and secondary windings are 2 and 4, respectively. Inductor core has air gap of $0.4 \mathrm{~mm}$, and turn number of one-side winding is 2 . The all windings were formed with $175 \mu \mathrm{m}$ copper pattern in main-board, and their measured inductances are summarized in Table II.

\section{Experimental results}

The input voltage of port $\mathrm{B}$ is set to $V_{\mathrm{B}}=100 \mathrm{~V}$, and output voltage of port $\mathrm{A}$ and port $\mathrm{C}$ are controlled as $V_{\mathrm{A}}=48 \mathrm{~V}$ and $V_{\mathrm{C}}=12 \mathrm{~V}$ by adjusting $\phi$ and $\delta$ with each PI (Proportional-integral) controller. The electric loads are connected to port A and port C. Then, input power of $P_{\mathrm{B}}$ and output power of $P_{\mathrm{A}}$ and $P_{\mathrm{C}}$ are measured by a power scope (Yokogawa, PX-8000). Fig. 7 shows the experimental voltage and current waveforms at $P_{\mathrm{A}}=100 \mathrm{~W}, P_{\mathrm{C}}=400 \mathrm{~W}$. In Fig. 7, $\phi$ and $\delta$ were controlled as $\phi=0.1 \mathrm{rad}(40 \mathrm{~ns})$ and $\delta=4.65 \mathrm{rad}(1.85 \mu \mathrm{s})$, respectively. Then, the output voltages of $V_{\mathrm{A}}$ and $V_{\mathrm{C}}$ were measured as $V_{\mathrm{A}}=48 \mathrm{~V}$ and $V_{\mathrm{C}}=12 \mathrm{~V}$ constant. The inductor current waveform of $i_{\mathrm{u}}$ has a DC offset of $15 \mathrm{~A}$ because of multi-phase converter operation. From this, the parallel operation of two topologies in Fig. 3 was verified, and the prototype can be operated at rated power of $500 \mathrm{~W}$. Then, the

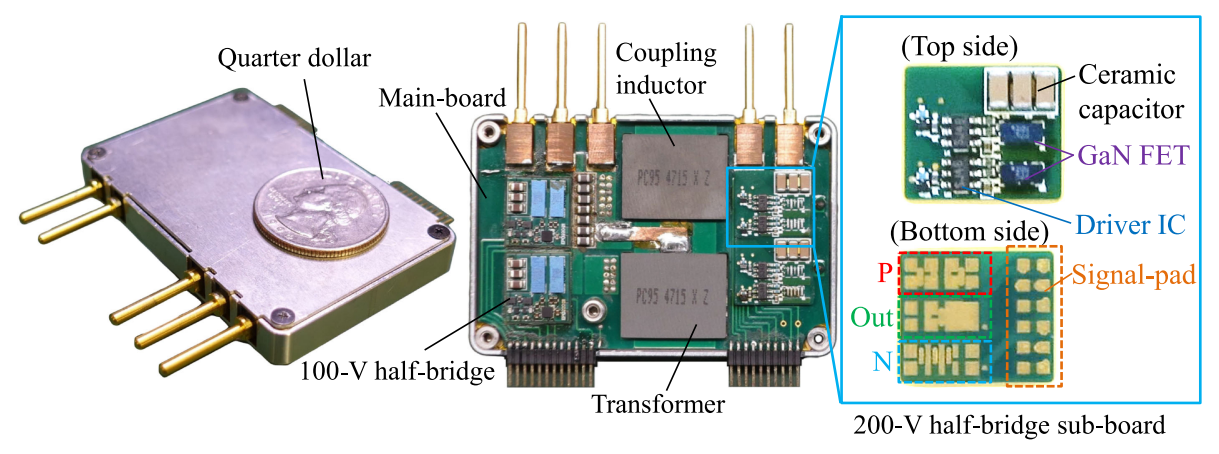

Fig. 6. Prototype of three-port converter cell with GaN FETs.

Table II. Basic circuit parameters

\begin{tabular}{l|c|c}
\hline Switching frequency & $f_{\mathrm{sw}}$ & $400 \mathrm{kHz}$ \\
\hline Rated power & $P_{\max }$ & $500 \mathrm{~W}$ \\
\hline Size & $\mathrm{W} * \mathrm{D} * \mathrm{H}$ & $6 * 4 * 0.75 \mathrm{~cm}$ \\
\hline Rated voltage & $V_{\mathrm{A}}, V_{\mathrm{B}}, V_{\mathrm{C}}$ & $48 \mathrm{~V}, 100 \mathrm{~V}, 12 \mathrm{~V}$ \\
\hline Core material of magnetic components & - & PC95EL18X7.3-Z \\
\hline Turn number (ratio) of transformer & $N$ & $2: 4(2)$ \\
\hline Magnetizing inductance of trans. [primary] & $L_{\mathrm{Trl}}$ & $10.74 \mu \mathrm{H}$ \\
\hline Coupling coefficient of transformer & $k_{\mathrm{t}}$ & 0.996 \\
\hline Air gap length of inductor & $l_{\mathrm{g}}$ & $0.4 \mathrm{~mm}$ \\
\hline Turn number of inductor & - & $2: 2$ \\
\hline Self inductance of inductor & $L_{\mathrm{u}}, L_{\mathrm{v}}$ & $0.74 \mu \mathrm{H}$ \\
\hline Coupling coefficient of inductor & $k_{\mathrm{L}}$ & 0.90 \\
\hline Dead time & $T_{\mathrm{d}}$ & $25 \mathrm{~ns}$ \\
\hline
\end{tabular}




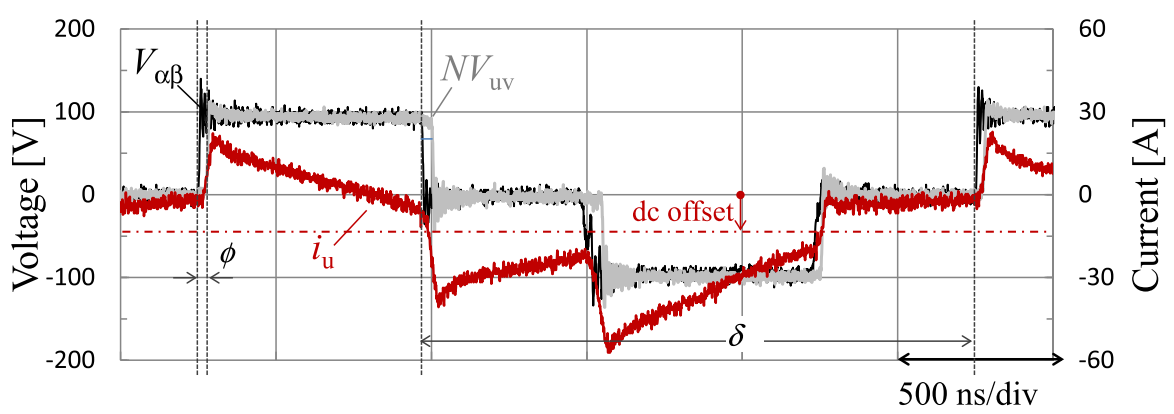

Fig. 7. Measured transformer terminal voltage $V_{\mathrm{uv}}, V_{\alpha \beta}$ and inductor current $i_{\mathrm{u}}$ at $P_{\mathrm{A}}=100 \mathrm{~W}, P_{\mathrm{C}}=400 \mathrm{~W}$

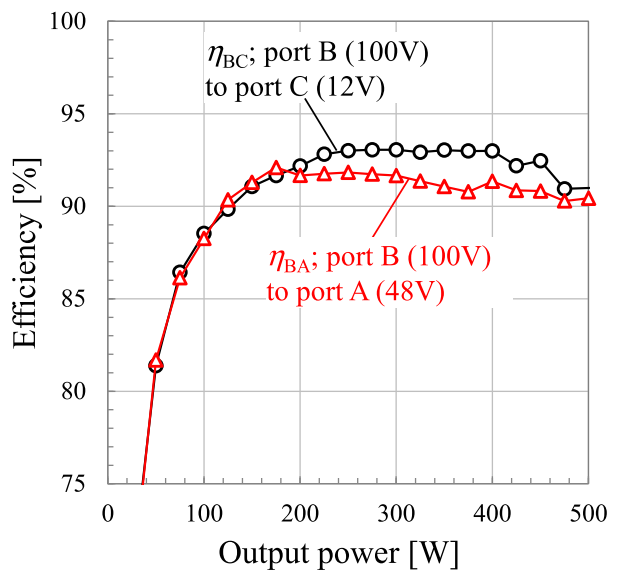

(a)

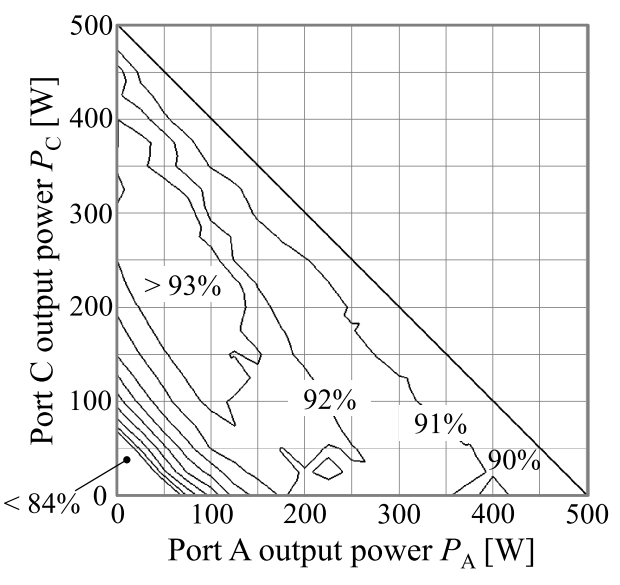

(b)

Fig. 8. (a) Measured efficiency curves for each output port, and (b) Measured efficiency map in parallel load condition.

power density of $28 \mathrm{~W} / \mathrm{cm}^{3}\left(=500 \mathrm{~W} / 18 \mathrm{~cm}^{3}\right)$ was achieved. Fig. $8($ a) shows the measured efficiency curves in single load condition. The efficiency of $\eta_{\mathrm{BC}}=$ $93.1 \%$ at $P_{\mathrm{C}}=300 \mathrm{~W}$ and $\eta_{\mathrm{BA}}=91.8 \%$ at $P_{\mathrm{A}}=250 \mathrm{~W}$ were achieved, respectively. Fig. 8(b) shows the efficiency map in parallel load condition. High efficiency of more than $91 \%$ was measured in wide output power range, with maximum efficiency of $93.7 \%$ at $P_{\mathrm{C}}=175 \mathrm{~W}$ and $P_{\mathrm{A}}=100 \mathrm{~W}$.

\section{Conclusion}

In the present work, high power density three-port converter with GaN FET has been developed and evaluated as a converter-cell for realizing compact and high efficient $12-\mathrm{V} / 48-\mathrm{V}$ dual-voltage HEV subsystem. The $500 \mathrm{~W}, 400 \mathrm{kHz}$ prototype achieved high power density of $28 \mathrm{~cm}^{3}$ at rated power, and high efficiency of $91 \%$ was measured over a wide output power range, with the maximum efficiency of $93.7 \%$. The newly developed three-port converter cell will allow us to reduce the number of cell and total volume if it is applied for the multi-cell structure of the $12-\mathrm{V} / 48-\mathrm{V}$ dual-voltage HEV subsystem, and also to increase the fuel efficiency due to low energy consumption. 